\title{
Zebrafish Embryo DNA Preparation
}

Lili Jing*

Department of Cell and Molecular Biology, University of Pennsylvania, Philadelphia, USA

*For correspondence: lilijingen@gmail.com

[Abstract] This protocol explains how to extract DNA from a single zebrafish embryo. It does not require the use of expensive kits.

\section{Materials and Reagents}

1. Proteinase K (Roche Diagnostics, catalog number: 03115836001)

2. $1 \mathrm{M}$ Tris $(\mathrm{pH} \mathrm{8.3)}$

3. $\mathrm{NaCl}$

4. $\mathrm{KCl}$

5. $\mathrm{CaCl}_{2} \cdot 2 \mathrm{H}_{2} \mathrm{O}$

6. $\mathrm{MgSO}_{4} \cdot 7 \mathrm{H}_{2} \mathrm{O}$

7. Sterile water

8. 10\%Tween 20 (EMD Biosciences, catalog number: 655207)

9. $10 \%$ NP40 (Merck KGaA, catalog number: 492018)

10. Embryo lysis buffer (see Recipes)

11. 1X PCR buffer (see Recipes)

12. E3 (see Recipes)

\section{Equipment}

1. PCR Thermal cycler

2. Centrifuges

3. Incubator

4. 96-well plate

\section{Procedure}

A. Freezing single live embryos

1. Wash dechorionated embryos $3 x$ with E3.

2. Place a single embryo into a well of a 96-well plate and remove all excess buffer. 
(Store dry at $-20^{\circ} \mathrm{C}$ if needed).

B. DNA preparation:

1. Add $50 \mu$ lysis buffer to single (live or in situ'd) embryos.

2. Incubate at $98{ }^{\circ} \mathrm{C}$ for 10 min to lyse cells. Spin down.

3. Add $5 \mu$ l Proteinase $\mathrm{K}(10 \mathrm{mg} / \mathrm{ml}$ stock) to single embryos.

4. Incubate at $55{ }^{\circ} \mathrm{C}$ for at least $2 \mathrm{~h}$ (longer the incubation, cleaner the DNA).

5. Incubate at $98^{\circ} \mathrm{C}$ to heat kill Proteinase $\mathrm{K}$.

6. Vortex thoroughly and spin down debris.

7. Use $2 \mu \mathrm{l}$ of single embryo DNA per PCR reaction.

\section{$\underline{\text { Recipes }}$}

1. 1X PCR buffer

For $50 \mathrm{ml}$

$10 \mathrm{mM}$ Tris- $\mathrm{HCl}(500 \mu \mathrm{l}$ of $1 \mathrm{M}$ Tris $)(\mathrm{pH} \mathrm{8.3)}$

$50 \mathrm{mM} \mathrm{KCl}(2.5 \mathrm{ml}$ of $1 \mathrm{M} \mathrm{KCl})$

$47 \mathrm{ml}$ sterile water

(Can be stored at RT for severalmonths)

2. Embryo lysis buffer (1X PCR buffer with tween 20 and NP40)

For $10 \mathrm{ml}$ of lysis buffer

$9.4 \mathrm{ml}$ 1x PCR buffer

$300 \mu \mathrm{l} \mathrm{NP40} \mathrm{(10 \%} \mathrm{stock)}{ }^{* * *}$ Make fresh

$300 \mu$ l tween 20 (10\% stock) each time***

3. E3

60x E3 stock (2 L)

$\begin{array}{ll}\mathrm{NaCl} & 34.4 \mathrm{~g} \\ \mathrm{KCl} & 1.52 \mathrm{~g} \\ \mathrm{CaCl}_{2} .2 \mathrm{H}_{2} \mathrm{O} & 5.8 \mathrm{~g} \\ \mathrm{MgSO}_{4 .} .7 \mathrm{H}_{2} \mathrm{O} & 9.8 \mathrm{~g}\end{array}$

Add distilled water up to $2,000 \mathrm{ml}$.

Store at RT.

To dilute to $1 x$ for rearing zebrafish, use $160 \mathrm{ml}$ of stock and fill to $10 \mathrm{~L}$ with $\mathrm{ddH}_{2} \mathrm{O}$ 


\section{Acknowledgments}

This protocol was developed in the Michael Granato Lab at University of Pennsylvania, Philadelphia, USA, and this work was supported by NIH grant R01HD037975. 